UDC 621.391

\title{
RESEARCH OF THE QUALITY CHARACTERISTICS OF SELF-SIMILAR TRAFFIC OF A MOBILE COMMUNICATION NETWORK ON THE BASIS OF SOFTWARE RELEASE
}

\author{
Irina V. Strelkovskaya, Irina N. Solovskaya, Anastasiya O. Makoganiuk, Andrii D. Balyk \\ Educational and Research Institute of Infocommunications and Software Engineering \\ O.S. Popov Odesa National Academy of Telecommunications, Odesa, Ukraine
}

\begin{abstract}
Background. At the planning and design stage of modern 3G/UMTS and 4G/LTE mobile networks, it is important to take into account that the traffic they serve is packet-based and has the property of self-similarity, which greatly complicates the determination of QoS characteristics.

Objective. The aim of the paper is to find the quality characteristics of the QoS of self-similar traffic described using the Weibull distribution for the $\mathrm{QS}$ of the form $\mathrm{W}_{\mathrm{B}} / \mathrm{M} / 1 / \infty$ using software release.

Methods. Methods of functional analysis, queuing theory, linear programming were used for the solution.

Results. The characteristics of the quality of service QoS self-similar traffic, namely the values of the average waiting time for service requests, the average number of requests in the queue and the average length of the queue of applications in the QS $\mathrm{W}_{\mathrm{B}} / \mathrm{M} / 1 / \infty$.

Conclusions. At the stage of frequency-territorial planning, design and further operation of 3G/UMTS and 4G/LTE networks, the found characteristics of the quality of service QoS will take into account the real values of traffic served by the base station NodeB (e-NodeB) for their optimal distribution of the service area.
\end{abstract}

Keywords: self-similar traffic; queuing system; QoS characteristics; Weibull distribution; Laplace-Stieltjes transformation; average waiting time for a claim; average number of claims in a queue; the average length of the queue of applications.

\section{Introduction}

At the planning and design stage of modern mobile communication networks 3G/UMTS (Universal Mobile Telecommunications System) and 4G/LTE (Long Term Evolution), it is quite important to take into account that the existing design methods are based on the assumption that mobile communication networks use circuit switching technologies, and the traffic they serve is described by the simplest (Poisson) call flow. The technological development of mobile communication networks today is based on packet switching. It is known [1] that the traffic served in such packet networks has a special structure and has the property of self-similarity, the main feature of which is the presence of a long-term dependence between the moments of packet arrival, which is determined by the correlation function at different times. As a quantitative assessment of the degree of self-similarity of traffic, the Hurst parameter is used, $0,5 \leq \mathrm{H}<1$ [1-3].

The rapid growth in the volume of subscriber traffic in the mobile network, a change in its nature and structure, a significant increase in bandwidth can contribute to possible overloads of network objects, their buffer devices and, accordingly, lead to delays and packet losses. Therefore, when servicing self-similar traffic, attention is paid to maintaining the characteristics of the quality of service QoS (Quality of Service).
In the design and further optimization of the 3G/UMTS and 4G/LTE mobile networks, when a variety of network structure and performance of network nodes, it is important to use methods of calculation which will take account of the traffic selfsimilarity. A number of questions arise, among which is the choice of distribution for describing self-similar traffic, which significantly differs from Poisson, most often these are Pareto, Weibull or lognormal distributions [1-3]. The choice of the method for calculating the QoS characteristics, since the use of the "classical methods" of the teletraffic theory based on the Poisson distribution does not allow obtaining reliable results, and the final solution for finding the QoS characteristics of self-similar traffic does not yet exist.

A significant number of works by various authors have been devoted to finding an estimate of the QoS characteristics of self-similar traffic [3-4]. And only for some cases of traffic description using various distributions, approximate solutions were obtained for some types of queuing systems (QS) using the Pollachek-Khinchin formula (QS of the form M/G/1), where the model of the flow of applications has an exponential distribution (M), the service time has an arbitrary distribution $(\mathrm{G})$, the QS is single-line and

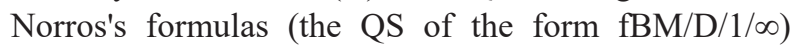
where the model of the flow of claims is described by fractal Brownian motion (fBM), the service time has a deterministic distribution (D), the QS is single-line with 
an endless queue. In [5-9], the authors considered selfsimilar traffic based on the Weibull distribution. Another method for finding the QoS quality characteristics of self-similar traffic based on the Laplace-Stieltjes transform is proposed. In this case, an integral equation was obtained, the solution of which does not always allow obtaining an exact analytical equation. Therefore, a software implementation of the solution of this integral equation is proposed.

The purpose of this work is to find the quality characteristics of the QoS of self-similar traffic described using the Weibull distribution for the QS of the form $W_{B} / M / 1 / \infty$ using software implementation using a software product.

\section{Program for the implementation of the interconnection of the integral level in the MATLAB}

Consider the Weibull distribution, which is given by a differential function [1]:

$$
f(x)=\left\{\begin{array}{ll}
\alpha \beta x^{\alpha-1} e^{-\beta x} \alpha & x \geq 0 \\
0, & x<0
\end{array},\right.
$$

where $\alpha$ - the parameter of the shape of the distribution curve $0<\alpha<1 ; \alpha=2-2 \mathrm{H}, \mathrm{H}-$ Hurst parameter, $0,5 \leq \mathrm{H}<1, \beta=\left[\lambda \Gamma\left(1+\frac{1}{\alpha}\right)\right]^{\alpha}-$ distribution parameter, $\beta>0, \lambda$ - packet traffic intensity, $\Gamma(k)-$ Euler's gamma function of the form $\Gamma(k)=\int_{0}^{+\infty} t^{k-1} e^{-1} d t$.

Find the features as self-similar traffic QoS for QS type $W_{B} / M / 1 / \infty$ (QS services to stream applications that are described Weibull distribution $\left(\mathrm{W}_{\mathrm{B}}\right)$, service time is exponential distribution (M), QS-tier with infinite queue) by the following formulas [11]: QS

- the average waiting time $W$ service requests in the

$$
W=\frac{\sigma}{\mu(1-\sigma)},
$$

where $\mu$-intensity of service requests in the QS, - the average number of requests $Q$ in the queue $\mathrm{QS}$

$$
Q=\frac{\rho \sigma}{\mu(1-\sigma)},
$$

where $\rho-$ is a load factor QS, QS

$$
L=\frac{\rho \sigma}{1-\sigma} .
$$

Finding the root $\sigma$ of equation (5) for the Weibull distribution is open until the next time.

Consider the solution using the Laplace-Stiltjes transformation [5-9]

$$
\sigma=F(\mu-\mu \sigma), 0 \leq \sigma<1,
$$

where $F$ - this is the Laplace-Stieltjes transform of the density of the distribution of the interval between the applications received in the $\mathrm{QS} \mathrm{W}_{\mathrm{B}} / \mathrm{M} / 1 / \infty$, which has the form

$$
F(s)=\int_{0}^{+\infty} e^{-s t} f(t) d t,
$$

where $s-$ complex variable, $\mu-$ intensity of service requests in the QS.

According to [5-9] equation (5) is equivalent to equation (6):

$$
\sigma=\alpha \beta \int_{0}^{+\infty} e^{-(\mu-\mu \sigma) t} t^{\alpha-1} e^{-\beta t} d t .
$$

Solve equation (6) graphically, i.e. by plotting functions

$$
y=\sigma, y=\alpha \beta \int_{0}^{+\infty} e^{-(\mu-\mu \sigma) t} t^{\alpha-1} e^{-\beta t} \alpha t .
$$

The point of intersection of both graphs of the above functions and will determine the root $\sigma$ of equation (6).

Solve the problem of finding the root $\sigma$ using the software implementation of the solution of the integral equation in the MATLAB, for this we make a program [10]:

$\% \exp =$ the exponent

$\% \mathrm{t}=$ time variable

$s=0.067: 0.001: 0.999 ; \% s=\sigma$, бо $0 \leq \sigma<1$

$\mathrm{h} 1=0.6$;

h2 $=0.7$;

h3 $=0.9$;

I1 = 0.5:0.1:1.5; \% $0.5 \leq \lambda \leq 1.5$

$\mathrm{n} 1=\left[\begin{array}{lllllll}0.5 & 0.75 & 1 & 1.25 & 1.5 & 2 & 2.25 \\ 2 & 2.5 & 2.75 & 3 & 3.25\end{array}\right]$;

$\% 0.5 \leq \mu \leq 3.25$

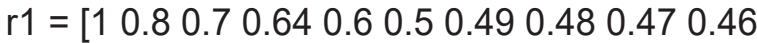

$0.45] ; \% 0.45 \leq \rho \leq 1$

f_intgr $=@(t, n, s, b, a) \exp \left(\left(-n+n^{*} s\right) .{ }^{*} t\right) .{ }^{*}$ t. ${ }^{\wedge}(a-$

1). ${ }^{*} \exp \left(-b^{*}\right.$ t.^a);

for $\mathrm{i}=1$ :length(s)

for $\mathrm{j}=1: 11$ 
$a 1=2-2 .{ }^{*} h(j) ; \% a=a$

funB1 = 1+1./a1;

$\mathrm{b} 1=\left(\mid 1(\mathrm{j})^{*} \operatorname{gamma}(\mathrm{funB} 1)\right) \cdot{ }^{\wedge} \mathrm{a} 1 ; \% \mathrm{~b}=\beta$,

gamma - Euler gamma function

a2 = 2-2. ${ }^{*} 2 ; \% a=\alpha$

funB2 = 1+1./a2;

$\mathrm{b} 2=(\text { I1(j) })^{*}$ gamma(funB2)).^a2; \%b = $\beta$,

gamma - Euler gamma function

a3 = 2-2. ${ }^{*}$ 3; $\% a=a$

funB3 = 1+1./a3;

b3 $=($ (I1(j)* gamma(funB3)).^a3; $\% b=\beta$,

gamma - Euler gamma function $\mathrm{y} 1(\mathrm{i}, \mathrm{j})=\mathrm{a} 1^{*} \mathrm{~b} 1{ }^{*}$ integral $(@(\mathrm{t})$

f_intgr(t,n1(j),s(i),b1,a1),0,100); \% H=0.6

$y 2(i, j)=a 2 * b 2 * i n t e g r a l(@(t)$

f_intgr(t,n1(j),s(i),b2,a2),0,100); \% H=0.7

$y 3(i, j)=a 3^{*} b 3 *$ integral $(@(t)$

f_intgr(t,n1(j),s(i),b3,a3),0,100); \% H=0.6

$\mathrm{W}(\mathrm{i}, \mathrm{j})=\mathrm{s}(\mathrm{i}) /\left(\mathrm{n} 1(\mathrm{j})^{*}(1-\mathrm{s}(\mathrm{i}))\right) ; \% \mathrm{~W}$

$\mathrm{Q}(\mathrm{i}, \mathrm{j})=\left(\mathrm{r} 1(\mathrm{j})^{*} \mathrm{~s}(\mathrm{i})\right) /\left(\mathrm{n} 1(\mathrm{j})^{*}(1-\mathrm{s}(\mathrm{i}))\right) ; \% \mathrm{Q}$

end

$L(i, j)=\left(r 1(j)^{*} s(i)\right) /(1-s(i)) ; \% L$

end

The results of calculations mentioned root of equation (6) provided the set intensity values flow $\lambda(0.5 \leq \lambda \leq 1.5)$ and service applications $\mu(0.5 \leq \mu \leq 3.25)$ to QS $W_{\mathrm{B}} / \mathrm{M} / 1 / \infty$, different settings of Weibull distribution and different parameter values of Hurst $\mathrm{H}(\mathrm{H}=0.6, \mathrm{H}=0.7, \mathrm{H}=0.9)$, which determine the degree of self-similarity of traffic (Table 1). In Fig. 1-3 is shown the solution of the equation (6) based on the parameters QS $W_{B} / M / 1 / \infty$.

Table 1. Results of solving the root $\sigma$ equation (6) for various parameters $\alpha, \beta$ of Weibull distribution and Hurst parameters if $\mathrm{H}=0.6, \mathrm{H}=0.7, \mathrm{H}=0.9$

\begin{tabular}{|c|c|c|c|c|c|c|c|c|c|c|c|}
\hline Parameter & \multicolumn{10}{|c|}{ Value } \\
\hline$\lambda$ & 0.5 & 0.6 & 0.7 & 0.8 & 0.9 & 1.0 & 1.1 & 1.2 & 1.3 & 1.4 & 1.5 \\
\hline$\mu$ & 0.5 & 0.75 & 1.0 & 1.25 & 1.5 & 2.0 & 2.25 & 2.5 & 2.75 & 3.0 & 3.25 \\
\hline \multicolumn{10}{|c|}{$\mathrm{H}=0.6, \alpha=0.8$} \\
\hline$\beta$ & 0.635 & 0.734 & 0.831 & 0.924 & 1.016 & 1.105 & 1.193 & 1.279 & 1.363 & 1.446 & 1.528 \\
\hline$\sigma(H=0.6)$ & 0.990 & 0.841 & 0.758 & 0.707 & 0.672 & 0.582 & 0.572 & 0.564 & 0.557 & 0.551 & 0.547 \\
\hline \multicolumn{10}{|c|}{$\mathrm{H}=0.7, \alpha=0.6$} \\
\hline$\beta$ & 0.843 & 0,940 & 1.032 & 1.118 & 1,199 & 1,278 & 1,353 & 1,425 & 1,496 & 1,564 & 1,63 \\
\hline$\sigma(H=0.7)$ & 0.913 & 0.894 & 0.834 & 0.795 & 0.769 & 0.697 & 0.688 & 0.681 & 0.675 & 0.671 & 0.667 \\
\hline \multicolumn{10}{|c|}{$\mathrm{H}=0.9, \alpha=0.2$} \\
\hline$\beta$ & 2.268 & 2.352 & 2.426 & 2.491 & 2.551 & 2.605 & 2.665 & 2.702 & 2.746 & 2.787 & 2.825 \\
\hline$\sigma(H=0.9)$ & 0.994 & 0.993 & 0.992 & 0.991 & 0.989 & 0.984 & 0.983 & 0.982 & 0.982 & 0.981 & 0.9801 \\
\hline
\end{tabular}

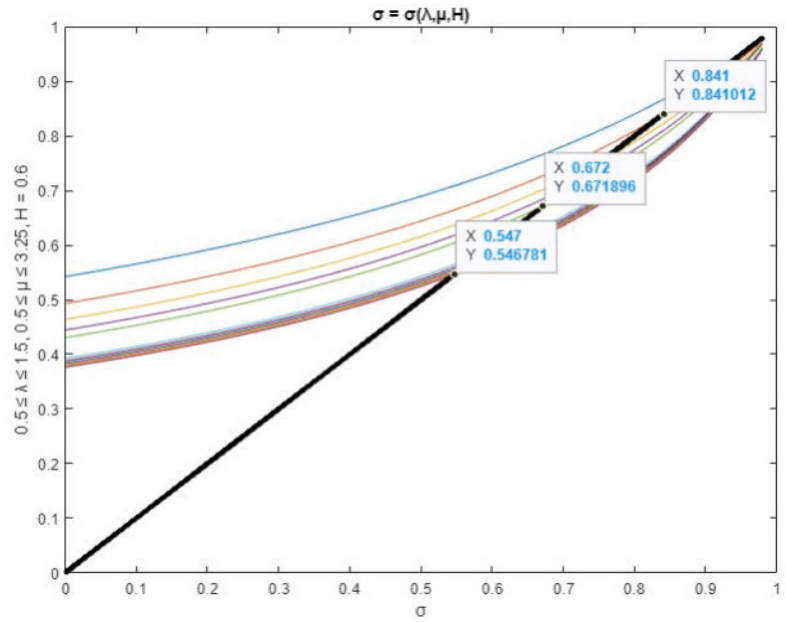

Fig. 1. Finding the root of $\sigma=\sigma(\lambda, \mu, \mathrm{H})$ equation (6) for the QS $\mathrm{W}_{\mathrm{B}} / \mathrm{M} / 1 / \infty$, for input data of Hurst parameter $\mathrm{H}=0.6$, $0.5 \leq \lambda \leq 1.5,0.5 \leq \mu \leq 3.25$

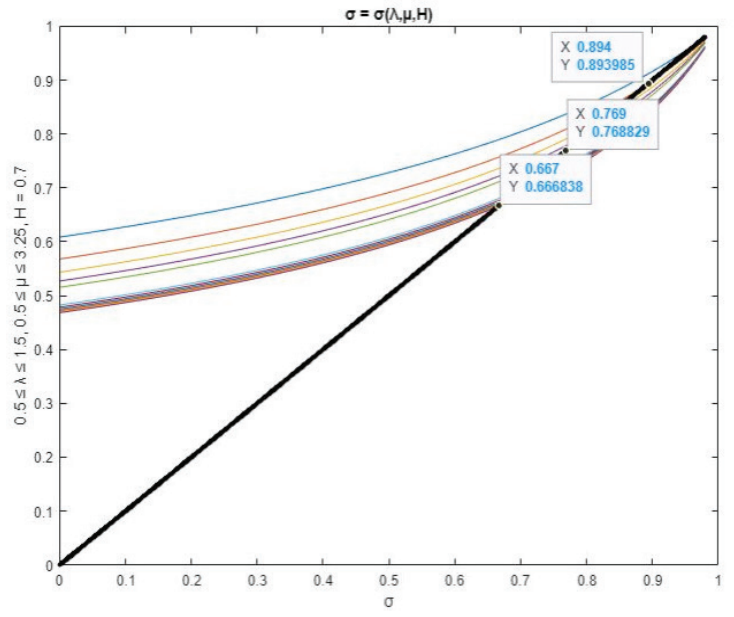

Fig. 2. Finding the root of $\sigma=\sigma(\lambda, \mu, H)$ equation (6) for the QS $W_{B} / M / 1 / \infty$, for input data of Hurst parameter $\mathrm{H}=0.7$, $0.5 \leq \lambda \leq 1.5,0.5 \leq \mu \leq 3.25$ 


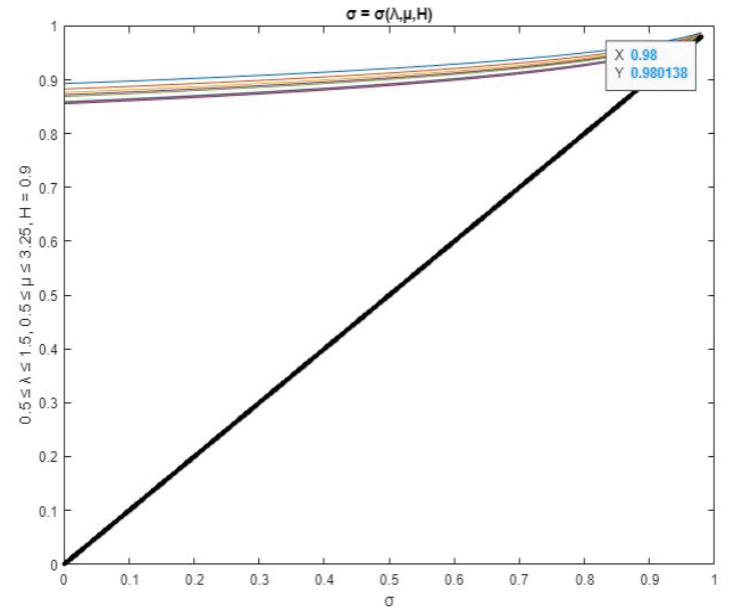

Fig. 3. Finding the root of $\sigma=\sigma(\lambda, \mu, \mathrm{H})$ equation (6) for the QS $\mathrm{W}_{\mathrm{B}} / \mathrm{M} / 1 / \infty$, for input data of Hurst parameter $\mathrm{H}=0.9$, $0.5 \leq \lambda \leq 1.5,0.5 \leq \mu \leq 3.25$

\section{Calculation of QoS quality characteristics using software implementation in the MATLAB}

After receiving the results of calculations roots $\sigma$ equation (6), we find the characteristics of service quality self-similar traffic QS type $\mathrm{W}_{\mathrm{B}} / \mathrm{M} / 1 / \infty$ : QS,

- the average waiting time $W$ service requests in the

- the average number of applications $Q$ queue queuing system,

- the average length $L$ of the queue of applications in QS.
To find quality characteristics for QoS queuing system type $W_{B} / M / 1 / \infty$, using the formula (2-4) draw up a program in MATLAB:

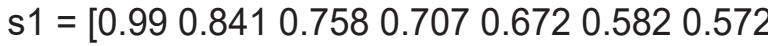

$0.5640 .5570 .5510 .547] ; \% \sigma(\mathrm{H}=0.6)$

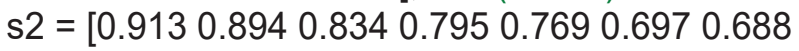

$0.6810 .6750 .6710 .667] ; \% \sigma(\mathrm{H}=0.7)$

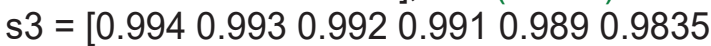

$0.98270 .9820 .98150 .9810 .9805] ; \% \sigma(\mathrm{H}=0.9)$

$11=0.5: 0.1: 1.5 ; \% 0.5 \leq \lambda \leq 1.5$

n1 = [0.5 0.75 11.251 .522 .252 .52 .753 3.25];

$\% 0.5 \leq \mu \leq 3.25$

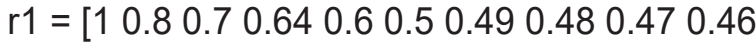

0.45 ]; $\% 0.45 \leq \rho \leq 1$

for $\mathrm{j}=1: 11$

$\mathrm{W} 1(\mathrm{j}, 1)=\mathrm{s} 1 \mathrm{r}(\mathrm{j}) /\left(\mathrm{n} 1(\mathrm{j})^{*}(1-\mathrm{s} 1 \mathrm{r}(\mathrm{j}))\right) ; \% \mathrm{~W}(\mathrm{H}=0.6)$

$\mathrm{Q} 1(\mathrm{j}, 1)=\left(\mathrm{r} 1(\mathrm{j})^{*} \mathrm{~s} 1 \mathrm{r}(\mathrm{j})\right) /\left(\mathrm{n} 1(\mathrm{j})^{*}(1-\mathrm{s} 1 \mathrm{r}(\mathrm{j}))\right) ; \%$

$\mathrm{Q}(\mathrm{H}=0.6)$

$\left.\mathrm{L} 1(\mathrm{j}, 1)=(\mathrm{r} 1 \mathrm{j})^{*} \mathrm{~s} 1 \mathrm{r}(\mathrm{j})\right) /(1-\mathrm{s} 1 \mathrm{r}(\mathrm{j})) ; \% \mathrm{~L}(\mathrm{H}=0.6)$

$\mathrm{W} 1(\mathrm{j}, 2)=\mathrm{s} 2 \mathrm{r}(\mathrm{j}) /\left(\mathrm{n} 1(\mathrm{j})^{*}(1-\mathrm{s} 2 \mathrm{r}(\mathrm{j}))\right) ; \% \mathrm{~W}(\mathrm{H}=0.7)$

$\mathrm{Q} 1(\mathrm{j}, 2)=\left(\mathrm{r} 1(\mathrm{j})^{*} \mathrm{~s} 2 \mathrm{r}(\mathrm{j})\right) /\left(\mathrm{n} 1(\mathrm{j})^{*}(1-\mathrm{s} 2 \mathrm{r}(\mathrm{j}))\right) ; \%$

$\mathrm{Q}(\mathrm{H}=0.7)$

$\mathrm{L} 1(\mathrm{j}, 2)=\left(\mathrm{r} 1(\mathrm{j})^{*} \mathrm{~s} 2 \mathrm{r}(\mathrm{j})\right) /(1-\mathrm{s} 2 \mathrm{r}(\mathrm{j})) ; \% \mathrm{~L}(\mathrm{H}=0.7)$

$\mathrm{W} 1(\mathrm{j}, 3)=\mathrm{s} 3 \mathrm{r}(\mathrm{j}) /\left(\mathrm{n} 1(\mathrm{j})^{*}(1-\mathrm{s} 3 \mathrm{r}(\mathrm{j}))\right) ; \% \mathrm{~W}(\mathrm{H}=0.9)$

$\mathrm{Q} 1(\mathrm{j}, 3)=\left(\mathrm{r} 1(\mathrm{j})^{*} \mathrm{~s} 3 \mathrm{r}(\mathrm{j})\right) /\left(\mathrm{n} 1(\mathrm{j})^{*}(1-\mathrm{s} 3 \mathrm{r}(\mathrm{j}))\right) ; \%$

$\mathrm{Q}(\mathrm{H}=0.9)$

$L 1(j, 3)=\left(r 1(j)^{*} s 3 r(j)\right) /(1-s 3 r(j)) ; \% L(H=0.9)$

for $i=1: 11$

$\mathrm{Q} 11(\mathrm{j}, \mathrm{i})=\left(\mathrm{r} 1(\mathrm{j})^{*} \mathrm{~s} 1 \mathrm{r}(\mathrm{j})\right) /\left(\mathrm{n} 1(\mathrm{i})^{*}(1-\mathrm{s} 1 \mathrm{r}(\mathrm{j}))\right) ; \% \mathrm{Q}(\rho$,

$\mu)$

end

end

The calculation results of characteristics of service quality self-similar traffic of $Q S$ type $W_{B} / M / 1 / \infty$ summarized in Table 2-4.

Table 2. Characteristics of service quality self-similar traffic type QS $\mathrm{W}_{\mathrm{B}} / \mathrm{M} / 1 / \infty$ at a given value of Hurst parameter $\mathrm{H}=0.6$

\begin{tabular}{|c|c|c|c|c|c|c|c|c|c|c|c|}
\hline$\lambda$ & 0.5 & 0.6 & 0.7 & 0,8 & 0.9 & 1.0 & 1.1 & 1.2 & 1.3 & 1.4 & 1.5 \\
\hline$\mu$ & 0.5 & 0.75 & 1.0 & 1.25 & 1.5 & 2.0 & 2.25 & 2.5 & 2.75 & 3.0 & 3.25 \\
\hline$\sigma$ & 0.990 & 0.841 & 0.758 & 0.707 & 0.672 & 0.582 & 0.572 & 0.564 & 0.557 & 0.551 & 0.547 \\
\hline$W$ & 198 & 7.052 & 3.132 & 1.930 & 1.365 & 0.696 & 0.594 & 0.517 & 0.457 & 0.409 & 0.371 \\
\hline$Q$ & 198 & 5.642 & 2.192 & 1.235 & 0.819 & 0.348 & 0.291 & 0.248 & 0.214 & 0.188 & 0.167 \\
\hline$L$ & 99 & 4.231 & 2.192 & 1.544 & 1.229 & 0.696 & 0.655 & 0.621 & 0.590 & 0.564 & 0.543 \\
\hline
\end{tabular}

Table 3. Characteristics of service quality self-similar traffic type QS $W_{B} / M / 1 / \infty$ at a given value of Hurst parameter $\mathrm{H}=0.7$

\begin{tabular}{|c|c|c|c|c|c|c|c|c|c|c|c|}
\hline$\lambda$ & 0.5 & 0.6 & 0.7 & 0,8 & 0.9 & 1.0 & 1.1 & 1.2 & 1.3 & 1.4 & 1.5 \\
\hline$\mu$ & 0.5 & 0.75 & 1.0 & 1.25 & 1.5 & 2.0 & 2.25 & 2.5 & 2.75 & 3.0 & 3.25 \\
\hline$\rho$ & 1 & 0.8 & 0.7 & 0.64 & 0,6 & 0.5 & 0.49 & 0.48 & 0.47 & 0.46 & 0.45 \\
\hline$\sigma$ & 0.913 & 0.894 & 0.834 & 0.795 & 0.769 & 0.697 & 0.688 & 0.681 & 0.675 & 0.671 & 0.667 \\
\hline$W$ & 20.98 & 11.245 & 5.024 & 3.102 & 2.219 & 1.150 & 0.980 & 0.853 & 0.755 & 0.679 & 0.616 \\
\hline$Q$ & 20.98 & 8.996 & 3.517 & 1.985 & 1.331 & 0.575 & 0.48 & 0.409 & 0.355 & 0.3127 & 0.277 \\
\hline
\end{tabular}




\begin{tabular}{|l|l|l|l|l|l|l|l|l|l|l|l|}
\hline$L$ & 10.49 & 6.747 & 3.517 & 2.482 & 1.997 & 1.15 & 1.08 & 1.024 & 0.976 & 0.938 & 0.901 \\
\hline
\end{tabular}

Table 4. Characteristics of service quality self-similar traffic type QS $\mathrm{W}_{\mathrm{B}} / \mathrm{M} / 1 / \infty$ at a given value of Hurst parameter $\mathrm{H}=0.9$

\begin{tabular}{|c|c|c|c|c|c|c|c|c|c|c|c|}
\hline$\lambda$ & 0.5 & 0.6 & 0.7 & 0,8 & 0.9 & 1.0 & 1.1 & 1.2 & 1.3 & 1.4 & 1.5 \\
\hline$\mu$ & 0.5 & 0.75 & 1.0 & 1.25 & 1.5 & 2.0 & 2.25 & 2.5 & 2.75 & 3.0 & 3.25 \\
\hline$\rho$ & 1 & 0.8 & 0.7 & 0.64 & 0,6 & 0.5 & 0.49 & 0.48 & 0.47 & 0.46 & 0.45 \\
\hline$\sigma$ & 0.994 & 0.993 & 0.992 & 0.991 & 0.989 & 0.983 & 0.982 & 0.982 & 0.982 & 0.981 & 0.980 \\
\hline$W$ & 331.33 & 151.31 & 86.8 & 56.377 & 35.964 & 14.901 & 12.37 & 10.475 & 9.067 & 7.917 & 6.962 \\
\hline$Q$ & 331.33 & 189.14 & 124 & 88.089 & 59.939 & 29.803 & 25.246 & 21.822 & 19.292 & 17.21 & 15.471 \\
\hline$L$ & 165.67 & 113.49 & 86.8 & 70.471 & 53.945 & 29.803 & 27.834 & 26.187 & 24.935 & 23.75 & 22.627 \\
\hline
\end{tabular}

According to the results of calculations, which are summarized in Table 2-4, construct graphs of average waiting time $W=W(\sigma)$ service requests in the QS type $\mathrm{W}_{\mathrm{B}} / \mathrm{M} / 1 / \infty$, the number of applications $Q$ in the queue QS type $\mathrm{W}_{\mathrm{B}} / \mathrm{M} / 1 / \infty$ queue length and type of applications $\mathrm{QS} \mathrm{W}_{\mathrm{B}} / \mathrm{M} / 1 / \infty$ for the value of Hurst parameter $\mathrm{H}=0.6$.

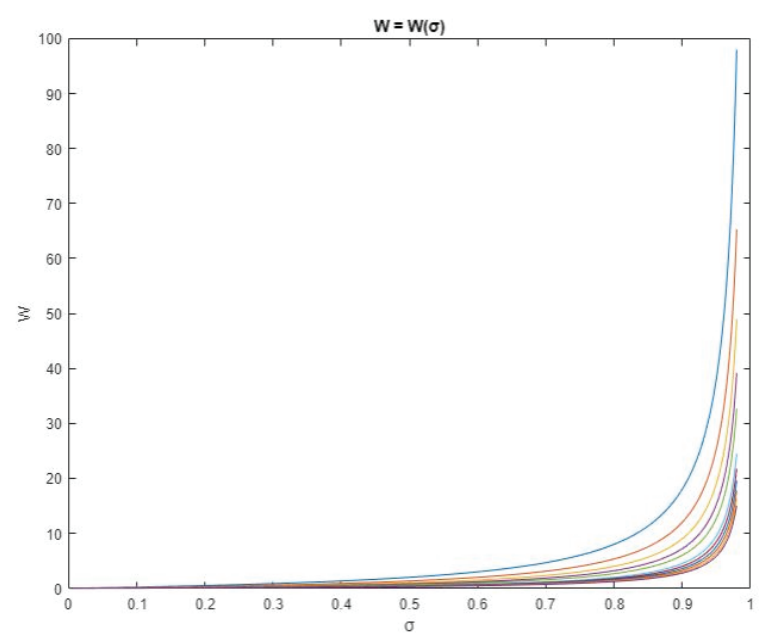

Fig. 4. Dependence of average waiting time $\mathrm{W}=\mathrm{W}(\sigma)$ for QS type $\mathrm{W}_{\mathrm{B}} / \mathrm{M} / 1 / \infty$ at input data of Hurst parameter $\mathrm{H}=0.6,0.5 \leq \lambda \leq 1.5,0.5 \leq \mu \leq 3.25$

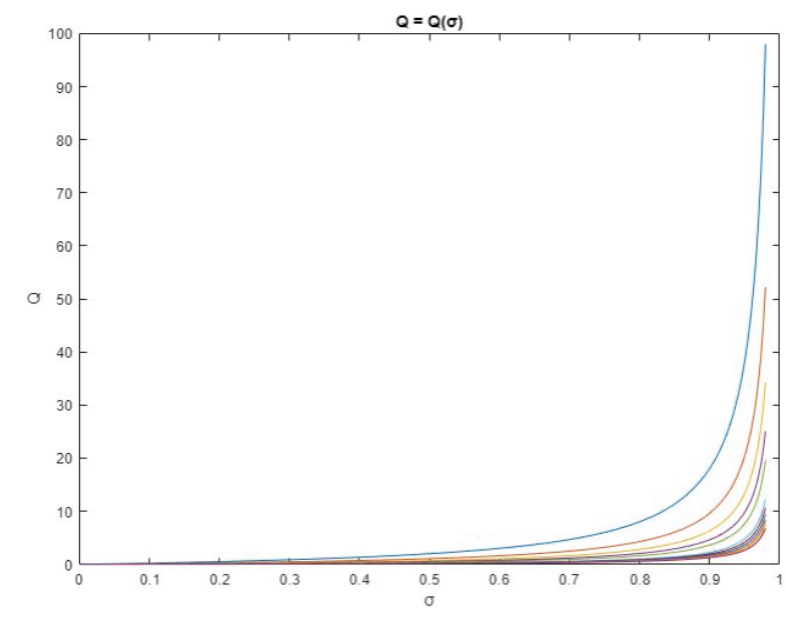

Fig. 5. Dependence of average number of applications $\mathrm{Q}=\mathrm{Q}(\sigma)$ for $\mathrm{QS}$ type $\mathrm{W}_{\mathrm{B}} / \mathrm{M} / 1 / \infty$ at input data of Hurst parameter $\mathrm{H}=0.6,0.5 \leq \lambda \leq 1.5,0.5 \leq \mu \leq 3.25$

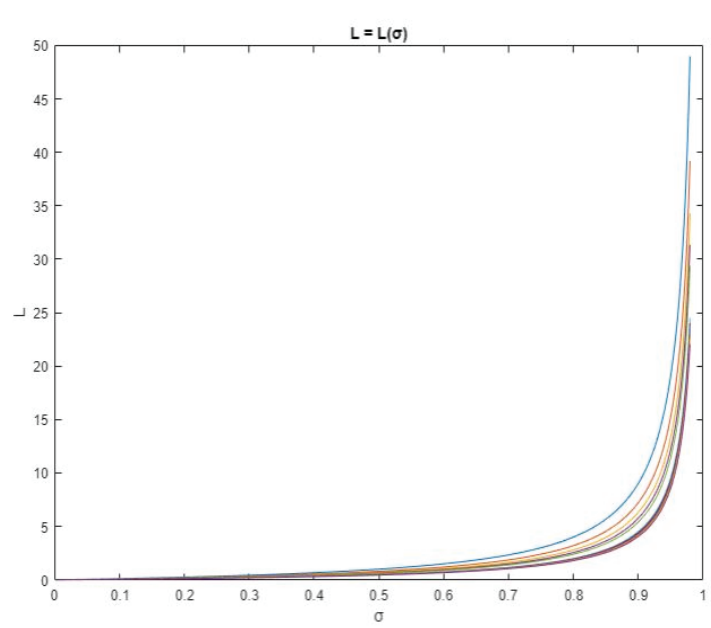

Fig. 6. Dependence requests queue length $\mathrm{L}=\mathrm{L}(\sigma)$ for $\mathrm{QS}$ type $\mathrm{W}_{\mathrm{B}} / \mathrm{M} / 1 / \infty$ at input data of Hurst parameter $\mathrm{H}=0.6$, $0.5 \leq \lambda \leq 1.5,0.5 \leq \mu \leq 3.25$

\section{Conclusions}

1. The queuing system of the type $\mathrm{W}_{\mathrm{B}} / \mathrm{M} / 1 / \infty$ is considered, which models the service of self-similar traffic on the basis of Weibull distribution.

2. To determine the quality characteristics of QoS queuing system type $W_{B} / M / 1 / \infty$ used integral equation is not always possible to get an accurate analytical solution. Therefore, a software implementation in the MATLAB environment for solving this equation is proposed in the paper.

3. Compiled program through which graphically solved integral equation, allowing determining the characteristics of service quality self-similar traffic QS $\mathrm{W}_{\mathrm{B}} / \mathrm{M} / 1 / \infty$, namely, the average waiting time in the QS application, the average number of applications in the QS and the average queue length of applications.

4. The obtained solutions allow providing practical recommendations for designing a mobile network, 
which can provide the required amount of buffer devices of network objects, thus enabling the provision of high-speed services, services and applications in the mobile operator's network with specified QoS quality parameters.

\section{References}

1. Krylov V.V. Theory of telegraphic and its applications / V.V. Krylov, S.S. Samohvalova. - SPb.: BXV-Petersburg, 2005.

2. Sheluhin O.I. Self-similarity and fractals. Telecommunication applications / O.I. Sheluhin, A.V. Osin, S.M. Smolskii, edited by O.I. Sheluhin. - M.: Phismatlit, 2008.

3. Prem Kumar Chaurasiya Comparative analysis of Weibull parameters for wind data measured from metmast and remote sensing techniques // Prem Kumar Chaurasiya, Siraj Ahmed, VilasWarudkar // Renewable Energy. - 2017. - Vol. 115. - pp. 1153-1165. https://doi.org/10.1016/j.renene.2017.08.014.

4. Millán G.A. Fast Multifractal Model for Self-Similar Traffic Flows in High-Speed Computer Networks / G.Millán, G.Lefranc // Procedia Computer Science. 2013. - Vol. 17. - pp. 420-425. https://doi.org/10.1016/j.procs.2013.05.054.

5. Strelkovskaya I. The solution to the problem of the QoS characteristics definition for self-similar traffic serviced by the W/M/1 QS / I. Strelkovskaya, I. Solovskaya, T. Grygoryeva, S. Paskalenko // Problems of Infocommunications Science and Technology: conference proceedings of the 2016 Third International Scientific-Practical Conference Proceedings (PICS\&T
2016), Kharkiv, Ukraine, October 4-6, 2016. - pp. 4042. https://doi.org/10.1109/infocommst.2016.7905330

6. Strelkovskaya I.V. Characterization of QoS quality of self-similar traffic for the QS W/M/1/ I.V. Strelkovskaya, T.I. Grigorieva, I.N. Solovskaya, S.A. Paskalenko, // Modern means of communication: proceedings of the XXI Intern. scientific and technical Conf., 20-21 October 2016: abstracts - Minsk, Rep. Belarus: Belarusian State Academy of Communications, 2016. - pp. 31-33.

7. Strelkovskaya I.V. Self-similar traffic in $G / M / 1$ queue defined by the Weibull distribution/ I.V. Strelkovskaya, T.I. Grygoryeva, I.N. Solovskaya // Radioelectronics and Communications Systems. 2018. - V. 61, № 3 (2018). - pp. 173-180.

8. Strelkovskaya I.V. Finding some QoS characteristics of self-similar traffic serviced by a mobile network / I.V. Strelkovskaya, I.N. Solovskaya, A.O. Makoganiuk $/ /$ Proceedings $2^{\text {nd }}$ IEEE International Conference Advanced Information and Communication Technologies-2017, Lviv, Ukraine, July 4-7, 2017. - P. 146-149. https://doi.org/10.1109/AIACT.2017.8020086 9. Strelkovskaya I. Estimation of QoS characteristics of self-similar traffic for the W/M/1 queuing system / I. Strelkovskaya, E. Siemens, I. Solovskaya, I. Fedotova// Collection of scientific papers O.S. Popov ONAT. - 2018. - Issue. 1. - pp. 27-33.

10. SIMULINK. User's Guide. Natick: The MathWorks, Inc., 1990.

11. Kleynrok L. Theory of queuing system service: [I.I. Grushko; transl from Eng.]. - M.: Engineering, 1979.

Стрелковська І.В., Соловська І.М., Балик А.Д., Макоганюк А.О.

Дослідження якісних характеристик самоподібного трафіку мережі мобільного зв'язку на основі релізації програмного забезпечення

Проблематика. На етапі планування і проектування сучасних мереж мобільного зв'язку 3G/UMTS i 4G/LTE важливо враховувати, що трафік, який в них обслуговується, $є$ пакетним і має властивість самоподібності, що значно ускладнює визначення характеристик якості обслуговування QoS.

Мета досліджень. Метою даної роботи є знаходження характеристик якості QoS самоподібного трафіку, описуваного за допомогою розподілу Вейбулла для $\mathrm{CMO}$ виду $\mathrm{W}_{\mathrm{B}} / \mathrm{M} / 1 / \infty$ за допомогою програмної релізації.

Методика реалізації. Для вирішення використані методи функціонального аналізу, теорії масового обслуговування, лінійного програмування.

Результати досліджень. Отримано характеристики якості обслуговування самоподібного трафіка QoS, a саме: значення середнього часу очікування обслуговування заявки, середньої кількості заявок в черзі та середньої довжини черги заявок в $\mathrm{CMO} \mathrm{W}_{\mathrm{B}} / \mathrm{M} / 1 / \infty$.

Висновки. На етапі частотно-територіального планування, проектування i подальшої експлуатації мереж 3G/UMTS i 4G/LTE знайдені характеристики якості обслуговування QoS дозволять враховувати реальні значення трафіку, що обслуговується базовою станцією NodeB (e-NodeB), для їх оптимального розподілу на території, що обслуговується.

Ключові слова: самоподібний трафік; система масового обслуговування; характеристики якості обслуговування QoS; розподіл Вейбулла; перетворення Лапласа-Стілтьєса; середній час очікування заявки; середнє кількості заявок в черзі; середня довжина черги заявок. 
Стрелковская И.В., Соловская И.Н., Балык А.Д., Макоганюк А.О.

Исследование качественных характеристик самоподобного трафика сети мобильной связи на основе релизации программного обеспечения

Проблематика. На этапе планирования и проектирования современных сетей мобильной связи 3G/UMTS и 4G/LTE важно учитывать, что трафик, который в них обслуживается, является пакетным и обладает свойством самоподобия, что значительно усложняет определение характеристик качества обслуживания QoS.

Цель исследований. Целью данной работы является нахождение характеристик качества QoS самоподобного трафика, описываемого с помощью распределения Вейбулла для $\mathrm{CMO}$ вида $\mathrm{W}_{\mathrm{B}} / \mathrm{M} / 1 / \infty$ с помощью программной релизации.

Методика реализации. Для решения использованы методы функционального анализа, теория массового обслуживания, линейное программирование.

Результаты исследований. Получены характеристики качества обслуживания самоподобного трафика QoS, a именно: значения среднего времени ожидания обслуживания заявки, среднего количества заявок в очереди и средней длины очереди заявок в $\mathrm{CMO} \mathrm{W}_{\mathrm{B}} / \mathrm{M} / 1 / \infty$.

Выводы. На этапе частотно-территориального планирования, проектирования и дальнейшей эксплуатации сетей 3G/UMTS и 4G/LTE найденные характеристики качества обслуживания QoS позволят учитывать реальные значения трафика, обслуживаемого базовой станцией NodeB (e-NodeB), для их оптимального распределения на обслуживаемой территории.

Ключевые слова: самоподобный трафик; система массового обслуживания; характеристики качества обслуживания QoS; распределение Вейбулла; преобразование Лапласа-Стилтьеса; среднее время ожидания заявки; среднее количества заявок в очереди; средняя длина очереди заявок. 